\title{
The Effectiveness of Closed Reduction Method Using Chinese Finger Trap and Immobilization of Circular Casts in the Management of Distal Radius Closed Fractures
}

\author{
Clement Dewanto ${ }^{1}$, Zulkarnain Muslim ${ }^{1 *}$ \\ ${ }^{1}$ Department of Surgery, Faculty of Medicine, Universitas Sriwijaya, Indonesia \\ *Correspondence Author Email: zulkarnainmuslim@gmail.com
}

\begin{abstract}
Introduction. Distal radius fractures are one of the most common fractures encountered by bone surgeons in the emergency room. In America, accounting for about $8 \%$ to $17 \%$ of all fracture cases that have been treated and around $75 \%$ of fractures in the forearm. In Palembang, especially in Dr. Moh Hoesin general hospital there was no data yet about the number of incidents of distal radius fractures, how to treat (conservatively or operatively) and success rates. For this reason it is difficult to measure accurately, how likely is it that a distal radius fracture can be successfully treated conservatively.

Methods. This study was an observational analytic study with a longitudinal design to determine the effectiveness of closed reduction measures by immobilization casting through radiological examination in the management of cases of distal radius fractures at dr Moh Hoesin general hospital in Palembang

Result. Based on the subject based on the type of fracture, there were $43.8 \%$ of subjects with Frykman-1; 6.3\% of subjects with Frykman-2; 18.8\% of subjects with Frykman-3; $12.5 \%$ subjects with Frykman-4; 6.3\% of subjects with Frykman-5; 0\% of subjects with Frykman-6; 6.3\% of subjects with Frykman-7; 6.3\% of subjects with Frykman-8. Based on the analysis between the Fracture Type and X-Ray parameters in the form of Radial Length, Radial Inclination, Radial Tilt and Ulnar Variance, only Ulnar Variance has a significant relationship with $\mathrm{p}=0.001$
\end{abstract}




\section{SSS SRIWIJAYA JOURNAL OFSURGERY}

Conclusion. The effectiveness of closed reduction is significantly related to the type of Frykman fracture and the most fracture type that has been successfully closed closed is the type of Frykman I fracture with the highest number of samples and $100 \%$ success rate.

\section{Keyword: closed reduction, chinese finger trap, circular cast, distal radius fracture}

\section{Introduction}

Distal radius fractures are one of the most common fractures encountered by bone surgeons in the emergency room. In America, accounting for about $8 \%$ to $17 \%$ of all fracture cases that have been treated and around $75 \%$ of fractures in the forearm. ${ }^{1.2}$ The distribution of these injuries is most often found specifically in 2 age groups, namely in ages 5-14 years and in the age group above 60 years. ${ }^{1}$ Most distal radius fractures are also more common in women with a ratio of 4 : 1.1

In China, Jian Fen reports a $17 \%$ distal radius fracture incidence from all fracture incidents. ${ }^{2}$ In India the incidence rate is reported to be $20 \%$ of the total fractures treated in the emergency room. ${ }^{3}$ In Sweden, the incidence of distal radius metaphysical fractures is 24 per 10,000 people / year. With a ratio between women and men as much as 3: 1. At the Dr. M. Djamil general hospital, Padang, there were 122 cases out of 612 total distal radius fracture cases, from the time span of January 2011 to June $2012 .^{4}$

Indonesian Basic Health Research Data 2013 shows that broken bones experienced by 5.8\% of the population. In populations aged $\geq 75$ years, the percentage is higher at $10 \%{ }^{2}$ However, there are no specific national epidemiological data in Indonesia regarding distal radius fractures. A study at one hospital in Indonesia showed that the percentage of distal radius fractures was $52.2 \%$ of the incidence of physis bone fractures in children aged 0-14 years. Another study showed that more distal radius fractures were experienced by men (56.7\%), age late adolescents (17-25 years as many as $32.8 \%$ with the most common causes namely accidents (85\%) and trauma falls (14.9\%).

Based on epidemiological studies, distal radius fractures occur in combination of several different fracture patterns. It is still a difficult challenge to determine in real terms whether the 


\section{STS SRIWIJAYA JOURNAB OFEURGERY}

injury is extra-articular or intra-articular, even more complex, it is difficult to determine whether the fracture is a stable or unstable fracture. ${ }^{7}$

In Palembang, especially in Dr. Moh Hoesin general hospital there was no data yet about the number of incidents of distal radius fractures, how to treat (conservatively or operatively) and success rates. For this reason it is difficult to measure accurately, how likely is it that a distal radius fracture can be successfully treated conservatively.

The majority of distal radius fractures can be treated conservatively (non-operatively). The procedure involves a reduction in the effect of anesthesia if the fracture is displaced, and immobilization of the forearm using a cast for about 6 weeks. It is said that all displaced fractures should be closed reduction even if surgical treatment is needed in the future. ${ }^{8}$ The Cochrane review clearly shows the benefits and the appropriate time to reduce fractures as well as the conservative methods used to stabilize reduced fractures and evaluate the main methods of anesthesia. and physical techniques used during the reduction and operation

DS Wendling's study in Berlin in 2014 found results from 263 cases that were managed by closed reduction and immobilization of circular casts, only 38 cases required secondary intervention. ${ }^{9}$ The most fundamental decision that must be taken when dealing with distal radius fracture cases is whether the case can be handled conservatively or must be treated through surgery. Several factors, such as age, bone quality, occupation and general condition of the patient along with the characteristics of the fracture itself and the experiences of the bone surgeon, must all be considered in making decisions in determining the best course of action. ${ }^{10}$ Closed reduction and immobilization with casts has an important role in the treatment of cases of distal radius fractures, especially in children. ${ }^{9}$ But various results regarding failure in reducing broken bones have also been raised in various literature and therefore a lot of research was then carried out to identify factors which causes an increased risk of failure of these actions. ${ }^{11}$ One of the studies conducted mentioned in a meta-analytic involving 404 patients mentioned no significant differences in anatomical results and complications obtained based on closed reduction techniques and immobilization therapy. Including anesthetic techniques, type of traction, immobilization position. ${ }^{10}$

This study aimed to assess the effectiveness of closed reduction followed by immobilization of the cast in handling cases of distal radius fractures and what factors determine success in 


\section{SSS SRIWIJAYA JOURNAL OFSURGERY}

handling cases of distal radius fractures in achieving bone healing results and good function recovery.

\section{Methods}

This study was an observational analytic study with a longitudinal design to determine the effectiveness of closed reduction measures by immobilization casting through radiological examination in the management of cases of distal radius fractures at dr Moh Hoesin general hospital in Palembang. The study sample (16 people) were patients suffering from closed radius distal fractures who were treated at the Orthopedic Surgery Subdivision of the Department of Surgery at dr Moh Hoesin general hospital Palembang who had met the study inclusion criteria (inclusion and exclusion). Inclusion criteria were all patients with closed distal radius fractures, manipulation had not been done, acute cases / less than 7 days, aged over 14 years, willing to participate in the study and sign an informed concern sheet. Exclusion criteria were patients with distal radius segmental fractures, patients with multiple fractures of extremities on one side, patients with open fractures, pathological fractures (tumors or metabolic), patients with poor clinical condition.

Data analysis includes descriptive analysis and hypothesis testing. In descriptive analysis, categorical scale data such as age, sex and so on will be expressed as frequency and proportion distributions. Numeric-scale data is expressed as mean and standard deviation (SB) or median if the distribution is not normal. Description of data using tables and diagrams. Bi-variate data analysis was performed by testing the effectiveness of closed reduction actions with immobilized casts through radiographic examinations which then displayed their relationship to outcomes after closed reduction measures in table $2 \times 2$. The value of $p$ was considered significant if $p<0.05$ with $95 \%$ confidence intervals.

\section{Results}

The relationship between fracture types in subjects and the effectiveness of the closed reduction method can be seen in Table 1. In the distribution of subjects based on Fracture Type and Radial Length, there are $100 \%$ subjects with Frykman 1; 100\% subjects with Frykman 2; 100\% subjects with Frykman 3; 50\% of subjects with Frykman 4; 100\% subjects with Frykman 5; 100\% 


\section{SSS SRIWIJAYA JOURNABOFSURGERУ}

of subjects with Frykman 7; 100\% subjects with Frykman 8 in the Radial Length group with improvement, while there were 50\% subjects with Frykman 4 in the Radial Length group with no improvement.

In the distribution of subjects based on fracture type and radial inclination, there were $100 \%$ subjects with Frykman 1; $100 \%$ subjects with Frykman 2; $33.3 \%$ of subjects with Frykman 3; 50\% of subjects with Frykman 4; 100\% subjects with Frykman 5; 100\% subjects with Frykman 7 in the Radial Inclination group with improvement, while there were 66.7\% subjects with Frykman 3; $50.0 \%$ of subjects with Frykman 4; 100\% subjects with Frykman 8 in the Radial Inclination group with no improvement.

In the distribution of subjects by fracture type and radial tilt, there were $100 \%$ subjects with Frykman 1; 100\% subjects with Frykman 2; 100\% subjects with Frykman 5; 100\% subjects with Frykman 7 in the Radial Tilt group with improvement, while there were $100 \%$ subjects with Frykman 3; 100\% subjects with Frykman 4; 100\% subjects with Frykman 8 in the Radial Tilt group with no improvement.

In the distribution of subjects based on Fracture Type and Ulnar Variance, there were 100\% subjects with Frykman 1; $100 \%$ subjects with Frykman 2; $66.7 \%$ of subjects with Frykman 3; 50\% of subjects with Frykman 4; 100\% subjects with Frykman 5; 100\% of subjects with Frykman 7; $100 \%$ subjects with Frykman 8 in the Ulnar Variance group with improvement, while there were 33.3\% subjects with Frykman 3 and 50.0\% subjects with Frykman 4 in the Ulnar Variance group with no improvement.

In the distribution of subjects based on the Fracture Type and the final value of the success parameters, there were $100 \%$ subjects with Frykman 1; 100\% subjects with Frykman 2; 100\% subjects with Frykman 5; 100\% of subjects with Frykman 7; in the final grade group with improvement, while there were 100\% subjects with Frykman 3 and 100\% subjects with Frykman 4 and $100 \%$ subjects with Frykman 8 in the final grade group with no improvement. 


\section{SSS SRIWIJAYAJOURNABOPSURGERY}

Table 1. Subject distribution based on BMI to Radial Length

\begin{tabular}{|c|c|c|c|c|c|c|c|c|c|c|c|}
\hline \multirow{3}{*}{$\begin{array}{c}\text { Fraktur } \\
\text { Frykman } \\
\text { type }\end{array}$} & \multicolumn{10}{|c|}{ Success parameter } & \multirow{3}{*}{$\begin{array}{c}p \\
\text { value }\end{array}$} \\
\hline & \multicolumn{2}{|c|}{ Radial Length } & \multicolumn{2}{|c|}{ Radial Inclination } & \multicolumn{2}{|c|}{ Radial Tilt } & \multicolumn{2}{|c|}{ Ulnar Variance } & \multicolumn{2}{|c|}{ End value } & \\
\hline & + & - & + & - & + & - & + & - & + & - & \\
\hline I & $\begin{array}{c}7 \\
(100 \%)\end{array}$ & $\begin{array}{c}0 \\
(0 \%)\end{array}$ & $\begin{array}{c}7 \\
(100 \%)\end{array}$ & $\begin{array}{c}0 \\
(0 \%)\end{array}$ & $\begin{array}{c}7 \\
(100 \%)\end{array}$ & $\begin{array}{c}0 \\
(0 \%)\end{array}$ & $\begin{array}{c}7 \\
(100 \%)\end{array}$ & $\begin{array}{c}0 \\
(0 \%)\end{array}$ & $\begin{array}{c}7 \\
(100 \%)\end{array}$ & $\begin{array}{c}0 \\
(0 \%)\end{array}$ & \\
\hline II & $\begin{array}{c}1 \\
(100 \%)\end{array}$ & $\begin{array}{c}0 \\
(0,0 \%)\end{array}$ & $\begin{array}{c}1 \\
(100 \%)\end{array}$ & $\begin{array}{c}0 \\
(0,0 \%)\end{array}$ & $\begin{array}{c}1 \\
(100 \%)\end{array}$ & $\begin{array}{c}0 \\
(0,0 \%)\end{array}$ & $\begin{array}{c}1 \\
(100 \%)\end{array}$ & $\begin{array}{c}0 \\
(0,0 \%)\end{array}$ & $\begin{array}{c}1 \\
(100 \%)\end{array}$ & $\begin{array}{c}0 \\
(0,0 \%)\end{array}$ & \\
\hline III & $\begin{array}{c}3 \\
(100 \%)\end{array}$ & $\begin{array}{c}0 \\
(0 \%)\end{array}$ & $\begin{array}{c}1 \\
(33.3 \%)\end{array}$ & $\begin{array}{c}2 \\
(66.7 \%)\end{array}$ & $\begin{array}{c}0 \\
(0,0 \%)\end{array}$ & $\begin{array}{c}3 \\
(100,0 \%)\end{array}$ & $\begin{array}{c}2 \\
(66.7 \%)\end{array}$ & $\begin{array}{c}1 \\
(33.3 \%)\end{array}$ & $\begin{array}{c}0 \\
(0.0 \%)\end{array}$ & $\begin{array}{c}3 \\
(100.0 \%)\end{array}$ & \\
\hline IV & $\begin{array}{c}1 \\
(50.0 \%)\end{array}$ & $\begin{array}{c}1 \\
(50 \%)\end{array}$ & $\begin{array}{c}1 \\
(50.0 \%)\end{array}$ & $\begin{array}{c}1 \\
(50.0 \%)\end{array}$ & $\begin{array}{c}0 \\
(0,0 \%)\end{array}$ & $\begin{array}{c}2 \\
(100 \%)\end{array}$ & $\begin{array}{c}1 \\
(50.0 \%)\end{array}$ & $\begin{array}{c}1 \\
(50.0 \%)\end{array}$ & $\begin{array}{c}0 \\
(0.0 \%)\end{array}$ & $\begin{array}{c}2 \\
(100 \%)\end{array}$ & \\
\hline V & $\begin{array}{c}1 \\
(100 \%)\end{array}$ & $\begin{array}{c}0 \\
(0 \%)\end{array}$ & $\begin{array}{c}1 \\
(100 \%)\end{array}$ & $\begin{array}{c}0 \\
(0 \%)\end{array}$ & $\begin{array}{c}1 \\
(100 \%)\end{array}$ & $\begin{array}{c}0 \\
(0 \%)\end{array}$ & $\begin{array}{c}1 \\
(100 \%)\end{array}$ & $\begin{array}{c}0 \\
(0 \%)\end{array}$ & $\begin{array}{c}1 \\
(100 \%)\end{array}$ & $\begin{array}{c}0 \\
(0.0 \%)\end{array}$ & 0.001 \\
\hline VI & $\begin{array}{c}0 \\
(0 \%)\end{array}$ & $\begin{array}{c}0 \\
(0 \%)\end{array}$ & $\begin{array}{c}0 \\
(0 \%)\end{array}$ & $\begin{array}{c}0 \\
(0 \%)\end{array}$ & $\begin{array}{c}0 \\
(0 \%)\end{array}$ & $\begin{array}{c}0 \\
(0 \%)\end{array}$ & $\begin{array}{c}0 \\
(0 \%)\end{array}$ & $\begin{array}{c}0 \\
(0 \%)\end{array}$ & $\begin{array}{c}0 \\
(0 \%)\end{array}$ & $\begin{array}{c}0 \\
(0 \%)\end{array}$ & \\
\hline VII & $\begin{array}{c}1 \\
(100 \%)\end{array}$ & $\begin{array}{c}0 \\
(0 \%)\end{array}$ & $\begin{array}{c}1 \\
(100 \%)\end{array}$ & $\begin{array}{c}0 \\
(0 \%)\end{array}$ & $\begin{array}{c}1 \\
(100 \%)\end{array}$ & $\begin{array}{c}0 \\
(0 \%)\end{array}$ & $\begin{array}{c}1 \\
(100 \%)\end{array}$ & $\begin{array}{c}0 \\
(0 \%)\end{array}$ & $\begin{array}{c}1 \\
(100 \%)\end{array}$ & $\begin{array}{c}0 \\
(0.0 \%)\end{array}$ & \\
\hline VIII & $\begin{array}{c}1 \\
(100 \%)\end{array}$ & $\begin{array}{c}0 \\
(0 \%)\end{array}$ & $\begin{array}{c}0 \\
(0 \%)\end{array}$ & $\begin{array}{c}1 \\
(100 \%)\end{array}$ & $\begin{array}{c}0 \\
(0 \%)\end{array}$ & $\begin{array}{c}1 \\
(100 \%)\end{array}$ & $\begin{array}{c}1 \\
(100 \%)\end{array}$ & $\begin{array}{c}0 \\
(0 \%)\end{array}$ & $\begin{array}{c}0 \\
(0.0 \%)\end{array}$ & $\begin{array}{c}1 \\
(100 \%)\end{array}$ & \\
\hline
\end{tabular}

Note : The $\mathrm{p}$ value is obtained from the analysis of the fracture type and the final value of the success parameter

\section{Discussion}

The success of a closed reduction can be assessed from 3 factors in the form of Anatomical Outcome which is based on the results of radiological examination parameters such as radial length, shortening, dorsal angulation, radial inclination, such as the presence of a composite as a measure of malunion or deformity. Clinical outcome which includes swelling of soft tissue tissue, early and advanced complications associated with fractures, cosmetic appearance, the presence of osteoarthritis and patient satisfaction with treatment. Functional outcome which includes the ability of the hand, shoulder using the DASH score (disability of the arm, shoulder and hand), wrist evaluation (Patient Rate Wrist Evaluation / PRWE), can return to work and daily activities, presence of pain and range of motion, which is assessed through 6 parameters; 1) flexi; 2) Extensions; 3) Radial deviation; 4) Ulnar deviation; 5) pronation and 6) supination. Assessment based on Anatomical Outcome is one of the most accurate to see the progression and prognosis of 


\section{SISS SRIWIJAYA JOURNABOPSURGERУ}

the fracture. Based on the subject based on the type of fracture, there were $43.8 \%$ of subjects with Frykman-1; $6.3 \%$ of subjects with Frykman-2; 18.8\% of subjects with Frykman-3; 12.5\% subjects with Frykman-4; $6.3 \%$ of subjects with Frykman-5; 0\% of subjects with Frykman-6; 6.3\% of subjects with Frykman-7; 6.3\% of subjects with Frykman-8. Based on the analysis between the Fracture Type and X-Ray parameters in the form of Radial Length, Radial Inclination, Radial Tilt and Ulnar Variance, only Ulnar Variance has a significant relationship with $p=0.001$. When the fracture type is analyzed with the final value of the success parameter, a significant relationship is obtained with a value of $\mathrm{p}=0.001$. Frykman's classification is a classification of distal radius fractures which was introduced in 1967 and is formed based on the difference between extra and intra-articular fractures and the presence of distal ulna fractures. The use of distal radius fracture classification for predicting results is still debated. Frykman (1967) reports that, with its classification, the type of fracture is correlated with prognosis. Frykman 5-8 fractures have the worst prognosis. However, Tapio in 1998, stated that there was no significant difference in the type of Frykman fracture to the 5-year prognosis going forward.

\section{Conclusion}

The effectiveness of closed reduction is significantly related to the type of Frykman fracture and the most fracture type that has been successfully closed closed is the type of Frykman I fracture with the highest number of samples and $100 \%$ success rate.

\section{References}

1. Soeroso J., Isbagio H., Kalim H., Broto R., Pramudiyo R., 2007. Osteoarthritis, Dalam A.W Sudoyo, B.Setyohadi, I Alwi, M. Simadibrata, S. Setiati, editor, Buku Ajar Ilmu Penyakit Dalam Jilid II Edisi IV. Pusat Penerbitan Departemen Ilmu Penyakit Dalam FKUI. Jakarta.

2. Dulay G et al "Best practice and research clinical rheumatology." Knee pain, knee injury, knee osteoarthritis and work, vol.29, pp.454-461.

3. Anisa I P. Diagnosis and Treatment Osteoarthritis, Artikel review Volume 4 Nomor 4, Februari 2015. 


\section{STS SRIWIJAYA JOURNABOFEURGERY}

4. Johnson dan Hunter, The epidemiology of osteoartritis Best practice and research clinical rheumatology 2014).

5. Zhang et al Epidemiology of Osteoarthritis, Published in final edited form as Clin Geriatr Med. 2010 August ; 26 (3) : 355 - 369 doi:10.1016/j.cger.2010.03.001. NIH-PA Author Manuscript NIH-PA Author Manuscript NIH-PA Author Manuscript.

6. Hochberg et al, Amarican College of Rhematology 2012 Recommendation for the use of nonpharmacologic and pharmacologic Therapies in Osteoartritis of the hand, hip, and knee dalam Atritis care dan research vol 64, No. 4, April 2012.

7. Buttgereit et al, Non surgical management of knee osteoartritis, Reumatic \& musculoskeletal disease open first published as 10.1136 februari 2015).

8. Hacken B-et al. The Effects of Bariatric Surgery Weight Loss on Knee Pain in Patients with Knee Osteoarthritis: 2 Year Follow-up. J Arthritis 3: 132. doi: 10.4172/2167-7921.1000132, 2014.

9. Murphy L, Schwartz TA, Helmick CG, et al. Lifetime risk of symptomatic knee osteoarthritis. Arthritis Rheum. 2008;59(9):1207-13. [PMC free article] [PubMed].

10. Woolf, A.D. dan Pfleger, B., 2003, Burden of major musculoskeletal conditions, Buletin of the World Health Organization, 81(9), 646-656.

11. Koentjoro, Sara Listyani. 2010. Hubungan Antara Indeks Masa Tubuh (IMT) Dengan Derajat Osteoartritis Lutut Menurut Kellgren dan Lawrence. Artikel Hasil Penelitian Karya Tulis Ilmiah. Semarang: Fakultas Kedokteran. Universitas Diponegoro (http:// eprints.undip.ac.id) yang diakses tanggal 22 Januari 2018.

12. Rekomendasi IRA untuk Diagnosis dan Penatalaksanaan Osteoartritis. PAPDI. 2014.

13. Nur, M. 2009. Pengaruh Peningkatan Kualitas Hidup Penderita Osteoarthritis terhadap Perkembangan Industri Olahraga. Universitas Jember. Jember.

14. American Collge of Rheumatology 2012. Osteoathritis (http://www.rheumatology.org/, diakses 23 Juni 2013).

15. Akinpelu, AO et al, 2009. Prevalence and Pattern of Symptomatic Knee Osteoarthritis in Nigeria: A Community-Based Study The Internet Journal of Allied Health Sciences and Practice page 3-5, (http://ijahsp.nova.edu/articles/Vol7Num3/pdf/Akinpelufinal.pdf/, diakses 3 Januari 2014). 